\title{
Front Matter: Volume 9473
}

, "Front Matter: Volume 9473," Proc. SPIE 9473, Geospatial Informatics, Fusion, and Motion Video Analytics V, 947301 (12 June 2015); doi: $10.1117 / 12.2202224$

SPIE. Event: SPIE Defense + Security, 2015, Baltimore, MD, United States 


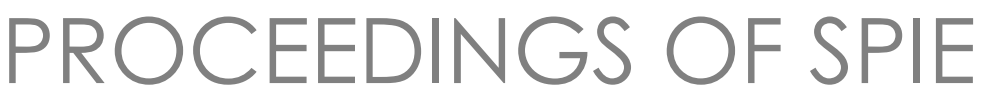

\title{
Geospatial Informatics, Fusion, and Motion Video Analytics V
}

\author{
Matthew F. Pellechia \\ Kannappan Palaniappan \\ Peter J. Doucette \\ Shiloh L. Dockstader \\ Gunasekaran Seetharaman \\ Editors
}

20-21 April 2015

Baltimore, Maryland, United States

Sponsored and Published by

SPIE

Volume 9473 
The papers included in this volume were part of the technical conference cited on the cover and title page. Papers were selected and subject to review by the editors and conference program committee. Some conference presentations may not be available for publication. The papers published in these proceedings reflect the work and thoughts of the authors and are published herein as submitted. The publisher is not responsible for the validity of the information or for any outcomes resulting from reliance thereon.

Please use the following format to cite material from this book:

Author(s), "Title of Paper," in Geospatial Informatics, Fusion, and Motion Video Analytics V, edited by Matthew F. Pellechia, Kannappan Palaniappan, Peter J. Doucette, Shiloh L. Dockstader, Gunasekaran Seetharaman, Proceedings of SPIE Vol. 9473 (SPIE, Bellingham, WA, 2015) Article CID Number.

ISSN: 0277-786X

ISBN: 9781628415896

Published by

SPIE

P.O. Box 10, Bellingham, Washington 98227-0010 USA

Telephone +1 3606763290 (Pacific Time) · Fax +1 3606471445

SPIE.org

Copyright (C) 2015, Society of Photo-Optical Instrumentation Engineers.

Copying of material in this book for internal or personal use, or for the internal or personal use of specific clients, beyond the fair use provisions granted by the U.S. Copyright Law is authorized by SPIE subject to payment of copying fees. The Transactional Reporting Service base fee for this volume is $\$ 18.00$ per article (or portion thereof), which should be paid directly to the Copyright Clearance Center (CCC), 222 Rosewood Drive, Danvers, MA 01923. Payment may also be made electronically through CCC Online at copyright.com. Other copying for republication, resale, advertising or promotion, or any form of systematic or multiple reproduction of any material in this book is prohibited except with permission in writing from the publisher. The CCC fee code is 0277-786X/15/\$18.00.

Printed in the United States of America.

Publication of record for individual papers is online in the SPIE Digital Library.

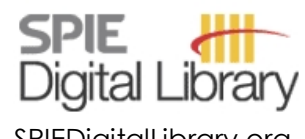

SPIEDigitalLibrary.org

Paper Numbering: Proceedings of SPIE follow an e-First publication model, with papers published first online and then in print. Papers are published as they are submitted and meet publication criteria. A unique citation identifier (CID) number is assigned to each article at the time of the first publication. Utilization of CIDs allows articles to be fully citable as soon as they are published online, and connects the same identifier to all online, print, and electronic versions of the publication. SPIE uses a six-digit CID article numbering system in which:

- The first four digits correspond to the SPIE volume number.

- The last two digits indicate publication order within the volume using a Base 36 numbering system employing both numerals and letters. These two-number sets start with 00, 01, 02, 03, 04, 05, 06, 07, 08, 09, OA, OB ... OZ, followed by 10-1Z, 20-2Z, etc.

The CID Number appears on each page of the manuscript. The complete citation is used on the first page, and an abbreviated version on subsequent pages. 


\title{
Contents
}

\author{
$\checkmark \quad$ Authors \\ vii Conference Committee \\ ix Introduction
}

SESSION 1 MOTION VIDEO ANALYTICS

947302 Streaming analysis of track data from video [9473-1]

947303 Illumination robust change detection with CMOS imaging sensors [9473-2]

947304 Cueing motion blur for registration of inclined planar scenes [9473-3]

947305 Object and activity detection from aerial video [9473-4]

947306 Application of VNIIRS for target tracking [9473-5]

947307 AESOP: Adaptive Event detection SOftware using Programming by example [9473-6]

SESSION 2 GEO-REGISTRATION AND UNCERTAINTY HANDLING IN GEOSPATIAL DATA

947309 Pedestrian dead reckoning using a novel sensor module that interfaces with modern smart devices [9473-8]

$94730 \mathrm{~A}$ Information fusion performance evaluation for motion imagery data using mutual information: initial study [9473-9]

$94730 \mathrm{C}$ Incorporating structure from motion uncertainty into image-based pose estimation [9473-11]

9473 OD Full motion video geopositioning algorithm integrated test bed [9473-12]

$9473 \mathrm{OE}$ Geostatistical modeling of uncertainty, simulation, and proposed applications in GIScience [9473-13]

\section{SESSION 3 ENABLING ARCHITECTURES FOR MULTI-DIMENSIONAL/MULTISENSING GIS}

9473 OF GeoMesa: a distributed architecture for spatio-temporal fusion [9473-14]

9473 OG Addressing fundamental architectural challenges of an activity-based intelligence and advanced analytics (ABIAA) system [9473-15]

9473 ol Semantically enabled image similarity search [9473-17] 


\section{SESSION 4 GEOINFORMATICS PROCESSING EXPLOITATION AND VISUALIZATION}

9473 OJ Effects of camera location on the reconstruction of 3D flare trajectory with two cameras [9473-18]

9473 OK Learning based roof style classification in 2D satellite images [9473-19]

$9473 \mathrm{OL}$ Context exploitation in intelligence, surveillance, and reconnaissance for detection and tracking algorithms [9473-20]

9473 ON Real-time automated detection, tracking, classification, and geolocation of dismounts using EO and IR FMV [9473-22] 


\section{Authors}

Numbers in the index correspond to the last two digits of the six-digit citation identifier (CID) article numbering system used in Proceedings of SPIE. The first four digits reflect the volume number. Base 36 numbering is employed for the last two digits and indicates the order of articles within the volume. Numbers start with 00, 01, 02, 03, 04, 05, 06, 07, 08, 09, 0A, 0B...0Z, followed by 10-1Z, 20-2Z, etc.

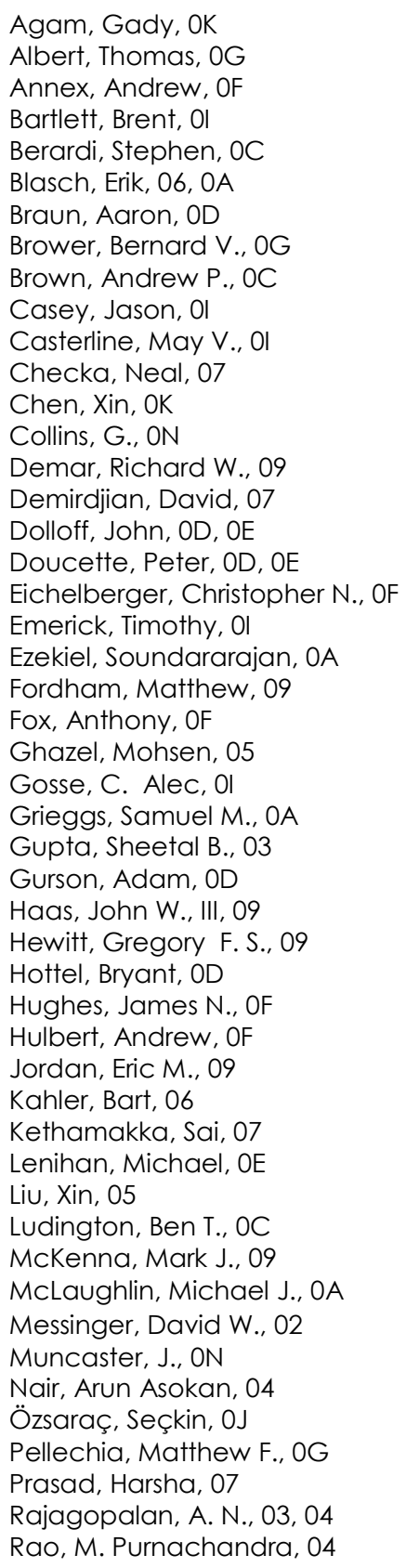

\author{
Rengarajan, Vijay, 03 \\ Ronquest, Michael, OF \\ Sadeghi, Kolia, Ol \\ Se, Stephen, 05 \\ Seetharaman, Guna, 03, 04 \\ Sheffler, Michael J., OC \\ Shi, Feng, 05 \\ Stanfill, S. Robert, OL \\ Stimac, Philip J., 09 \\ Sun, Jiangqin, 02 \\ Taylor, Clark N., OC \\ Thangali, Ashwin, 07 \\ Theiss, Henry, OD \\ Tucker, Jonathan D., OL \\ Waltman, J., ON \\ Yager, Kevin, OG \\ Yeşilkaya, Muhammed, OJ \\ Zang, Andi, OK \\ Zhang, Xi, OK
}


Proc. of SPIE Vol. $9473947301-6$

Downloaded From: https://www.spiedigitallibrary.org/conference-proceedings-of-spie on 26 Apr 2023 Terms of Use: https://www.spiedigitallibrary.org/terms-of-use 


\title{
Conference Committee
}

\author{
Symposium Chairs
}

Nils R. Sandell Jr., Strategic Technology Office, DARPA (United States)

Symposium Co-Chair

David A. Logan, BAE Systems (United States)

Conference Chairs

Matthew F. Pellechia, Exelis, Inc. (United States)

Kannappan Palaniappan, University of Missouri-Columbia

(United States)

Peter J. Doucette, Integrity Applications, Inc. (United States)

Shiloh L. Dockstader, Exelis, Inc. (United States)

Gunasekaran Seetharaman, Air Force Research Laboratory

(United States)

\section{Conference Program Committee}

John A. Berger, Toyon Research Corporation (United States)

Erik P. Blasch, Air Force Research Laboratory (Canada)

Bernard V. Brower, Exelis, Inc. (United States)

Subhasis Chaudhuri, Indian Institute of Technology Bombay (India)

Brian J. Daniel, Exelis Inc. (United States)

Larry S. Davis, University of Maryland, College Park (United States)

Mark A. Duchaineau, Google (United States)

Adel Hafiane, Ecole Nationale Supérieure d'Ingénieurs (France)

Simon J. Julier, University College London (United Kingdom)

Haibin Ling, Temple University (United States)

Peter Paul, Xerox Corporation (United States)

Robert B. Pless, Washington University in St. Lovis (United States)

V. B. Surya Prasath, University of Missouri-Columbia (United States)

Kari A. Pulli, NVIDIA Corporation (United States)

Ambasamudram Rajagopalan, Indian Institute of Technology Madras (India)

Raghuveer M. Rao, U.S. Army Research Laboratory (United States)

John A. Richards, Sandia National Laboratories (United States)

Sartaj Sahni, University of Florida (United States)

Carl Salvaggio, Rochester Institute of Technology (United States)

Stefano Soatto, University of California, Los Angeles (United States) 
Suresh Subramanian, Lockheed Martin Missiles and Fire Control

(United States)

Bruce Swett, EOIR Technologies (United States)

George R. Thoma, National Library of Medicine (United States)

Darrell L. Young, Raytheon Intelligence \& Information Systems

(United States)

Karmon M. Vongsy, Air Force Research Laboratory (United States)

\section{Session Chairs}

1 Motion Video Analytics

Gunasekaran Seetharaman, Air Force Research Laboratory (United States)

2 Geo-registration and Uncertainty Handling in Geospatial Data Shiloh L. Dockstader, Exelis Geospatial Systems (United States)

3 Enabling Architectures for Multi-Dimensional/Multisensing GIS Peter J. Doucette, Integrity Applications, Inc. (United States)

4 Geoinformatics Processing Exploitation and Visualization Matthew F. Pellechia, Exelis Geospatial Systems (United States) 


\section{Introduction}

Geoinformatics is the science and technology that develops and uses information science to address problems in the geosciences. A Geospatial Information System (GIS) describes any information system that collects, integrates, stores, edits, analyzes, shares, and displays geographic information. Geoinformatics and GIS are fundamental to today's information networks and inherently encompass techniques that transform "raw bits and bytes" into "actionable information", also termed InfoFusion. GIS applications incorporate tools that allow users to create interactive queries (user-created searches), analyze spatial information, edit data and maps, and present the results of all these operations. In the commercial sector, GIS is used in cartography, remote sensing, land surveying, utility management, geographical strategic natural resource planning, photogrammetric science, geography, urban planning, emergency management, navigation, and localized search engines. For example, defense and security applications, such as Unmanned Ariel Systems and Airport Security Systems, are rapidly transforming from basic sensor collection systems that "take pictures" to a fully capable GIS that incorporates multi-sensor collections, performs advanced processing and correlations in real-time, initiates sensor cross-cueing, and allows multiple users to instantly retrieve and disseminate information. Geoinformatics and GIS is critical to defense and security providers satisfying emerging demands and rapid access to information for situational awareness, forensic back-tracking, and activity-based intelligence (ABI) mission sets.

These proceedings provide the SPIE community with a collection of perspectives, advancements, learning, and new solutions from a range of global industry, government and academic authors. The motivation of this conference track is simple: to expand the awareness of advanced architectures and enabling technologies that address emerging, dynamic, and complex security threats. The solicited technical and scientific papers cover many topics: advancements in Video Analytics, Architectures for Multi-sensing Geospatial Collection, Data Processing Algorithms and Techniques, Information Dissemination, and Information Visualization Solutions that push beyond the scope of the state-of-the-art in industry.

On behalf of the conference chairs-Dr. Shiloh Dockstader, Dr. Peter Doucette, Dr. Kannappan Palaniappan, and Mr. Matthew Pellechia-we hope you find these proceedings useful in the advancement of GIS technologies.

\section{Shiloh Dockstader Peter Doucette Kannappan Palaniappan Matthew F. Pellechia}


Proc. of SPIE Vol. $9473947301-10$

Downloaded From: https://www.spiedigitallibrary.org/conference-proceedings-of-spie on 26 Apr 2023 Terms of Use: https://www.spiedigitallibrary.org/terms-of-use 